\title{
Impact of FDI Inflows on Export and Growth of an Indian Economy
}

\author{
S. Karpagalakshmi, A. Muthusamy
}

\begin{abstract}
FDI may be reflected as a resource for developing countries to get capital inflows, access to foreign technology, management skills and marketing networks. India is the world's highest rising economies and remains a top market for Foreign Direct Investments (FDI). In a globalizing world, export success can serve as much for the competitiveness of a country's industry and lead to faster growth. India is the most primary economies globally for foreign investment. It allows FDI of up to 100 percent of the equity shareholding in most sectors under the automatic route. The inflow of FDI into India is projected as able to increase productivity which will ultimately have an impact on the increase in national income in the form of the Gross Domestic Product (GDP) as well as in the form of increased exports. Exports support a country to increase its foreign exchange reserves, and build a strong financial position. FDI is seen as a potent tool of export promotion in the domestic country. This paper examines the most important benefits connected with the inflow of FDI as Export Performance, and GDP Growth. To study the dynamics of co-integration between FDI Inflow, GDP growth, and Export Performance, evidence is taken from country-specific level like Indian Economy where the period of study is from 2009-10 to2018-19. Hence, the paper studies the economic scenario of India for its FDI inflows, GDP growth rate, and its export performance. This paper attempt to analyze a positive correlation between FDI Inflow, GDP growth, and Export Performance by framing Simple Regression and Multiple Regression Models erected on the hypotheses formulated and validating the results of the models based on ANOVA and Durbin-Watson test.
\end{abstract}

Keywords : FDI, export, Global Economics, Inflow, ANOVA.

\section{INTRODUCTION}

Foreign Direct Investment refers to the shortest investment equity flows in the recording economy. It also stimulates global trade, enlarge domestic investment, and rise its foreign exchange reserves thereby improving its Balance of Payments position. All these factors as one supply to the growth of a nation. Export are also considered as a tool of economic growth and facilitate the efficient production of goods and services by gaining a proportional benefit over other countries. GDP growth rate is measured as annual percentage growth rate of GDP at fair prices based on constant local currency. Foreign companies carry with them many intangible assets in the form of abilities, technology, advertising tactics, product names, globally established

Revised Manuscript Received on September 25, 2019

Dr. S. KARPAGALAKSHMI, Teaching Assistant, Department of International Business, Alagappa University, Karaikudi-4, Tamil Nadu

Dr. A.MUTHUSAMY, Professor, Department of International Business, Alagappa University,Karaikudi-4, Tamil Nadu. marketing channels and experience of functioning in worldwide markets. The Foreign Direct Investment lift is essential to the rising capital, modernization, managerial know-how, advertising proficiency with access to global markets. Thus, the paper attempts to show an inter-relationship between FDI, GDP growth, and export performance. The sample data is derived from the relevant information of Indian Economy.

\section{NEED AND IMPORTANCE OF THE STUDY}

Foreign Direct Investment is monitored as a tool for export promotion. Foreign Direct Investment and exports are like two sides of a coin of the globalization process which not, only complementary to each other, but also mutually supportive. It helps to export activities by providing access to worldwide markets and enabling export-oriented production with an inflow of capital and access to modern technology. In other words, Foreign Direct Investment would improve the opportunities for India to participate in global specialization and other gains from trade. Besides Foreign Direct Investment, export orientation has also been hailed as an engine of growth. Foreign Direct Investment usually played an essential role in natural resource exports.

\section{OBJECTIVES OF THE STUDY}

The following are the objectives of the study

- To analyze the trend, growth, and patterns of FDI inflows into India.

- To study the correlation between FDI inflows, GDP growth, and Export perfomance.

- To study the dependence of GDP growth on Export performance and FDI inflows.

\section{PERIOD OF THE STUDY}

The study covers 10 years from 2009-10 to 2018-2019.

\section{METHODOLOGY OF THE STUDY}

The study is based on secondary data. Information required for the study has been collected from the RBI Statistics Database on Indian Economy. In this study, various statistical tools are used as Compound Annual Growth Rate, Trend, Growth rate, and Simple regression and Multiple regression and Correlation. The statistical 
significance of the variables is explained through the use of ANOVA and Durbin-Watson test.

\section{INFLOWS OF FDI: TREND AND PERFORMANCE}

Foreign Direct Investment (FDI) is a major source of non-debt monetary resource for the economic development of India. The Indian governments make favorable guidelines system, and well trade business location has ensured that foreign capital maintains flowing into the country. The Indian government has taken many ideas in recent years such as relaxing FDI norms across sectors such as defence, Public Sector Undertaking oil refineries, telecom, power exchanges, and stock exchanges, among others.

TABLE 1:FDI INFLOWS OF INDIA (Rs.in Billion)

\begin{tabular}{|c|c|c|c|c|}
\hline Year & $\begin{array}{c}\text { Total } \\
\text { FDI } \\
\text { Inflows } \\
\text { of } \\
\text { India } \\
\end{array}$ & Increase/Decrease & $\%$ & Trend \\
\hline $2009-1$ & 1578.1 & & & 1227.3 \\
\hline 0 & 9 & - & - & 7 \\
\hline $2010-1$ & 1323.5 & & -16.1 & 1429.3 \\
\hline 1 & 8 & -254.61 & 3 & 4 \\
\hline 2011-1 & 1549.6 & & & 1631.3 \\
\hline 2 & 1 & 226.03 & 17.08 & 0 \\
\hline $2012-1$ & 1469.5 & & & 1833.2 \\
\hline 3 & 4 & -80.07 & -5.17 & 6 \\
\hline 2013-1 & & & & 2035.2 \\
\hline 4 & 1868.3 & 398.76 & 27.14 & 3 \\
\hline 2014-1 & 2158.9 & & & 2237.1 \\
\hline 5 & 3 & 290.63 & 15.56 & 9 \\
\hline $2015-1$ & 2942.5 & & & 2439.1 \\
\hline 6 & 8 & 783.65 & 36.30 & 5 \\
\hline 2016-1 & 2832.9 & & & 2641.1 \\
\hline 7 & 2 & -109.66 & -3.73 & 2 \\
\hline $2017-1$ & 2539.7 & & -10.3 & 2843.0 \\
\hline 8 & 7 & -293.15 & 5 & 8 \\
\hline 2018-1 & 3098.6 & & & 3045.0 \\
\hline 9 & 7 & 558.9 & 22.01 & 4 \\
\hline CAGR & $6.98 \%$ & & & \\
\hline
\end{tabular}

Source: Computed

From Table 1, it could be seen that the FDI inflows of India were fluctuating between 1578.19 billion in 2009-10 to 3098.67 billion in 2018-19. The highest increase in FDI inflows of India is 36.30 percent in 2015-16 compared to previous years. The compound annual growth rate of FDI inflows of India was 6.98 percent during the study period. The trend values for FDI inflows of India 1227.37 billion in 2009-10 to 3045.04 billion in 2018-19 showing an increasing trend for 10 years.

\section{GDP GROWTH RATE OF INDIA}

India persists to occur in the grades of the world's largest economies. Its contribution to global GDP growth impetus will also increase. India will also play an increasingly vital role as one of the Asia-Pacific region's major economic growth engines, and ration to drive Asian regional trade and investment flows.

TABLE 2:GDP GROWTH RATE OF INDIA (Rs. in Billion)

\begin{tabular}{|l|r|r|r|r|}
\hline Year & \multicolumn{1}{|c|}{ GDP } & $\begin{array}{r}\text { Increase/ } \\
\text { Decrease }\end{array}$ & \multicolumn{1}{c|}{$\%$} & \multicolumn{1}{l|}{ Trend } \\
\hline $2009-10$ & 61089.03 & - & - & 64238.65 \\
\hline $2010-11$ & 72488.6 & 11399.57 & 18.66 & 72621.64 \\
\hline $2011-12$ & 83916.91 & 11428.31 & 15.77 & 81004.63 \\
\hline $2012-13$ & 92130.17 & 8213.26 & 9.79 & 89387.61 \\
\hline $2013-14$ & 98013.7 & 5883.53 & 6.39 & 97770.6 \\
\hline $2014-15$ & 105276.7 & 7263.04 & 7.41 & 106153.6 \\
\hline $2015-16$ & 113861.5 & 8584.71 & 8.15 & 114536.6 \\
\hline $2016-17$ & 121960.1 & 8098.61 & 7.11 & 122919.6 \\
\hline $2017-18$ & 130108.4 & 8148.37 & 6.68 & 131302.6 \\
\hline $2018-19$ & 140775.9 & 10667.47 & 8.20 & 139685.6 \\
\hline CAGR & $8.71 \%$ & & & \\
\hline
\end{tabular}

Source: Computed

Table 2 shows that GDP Growth Rate of India was increasing 61089.03 in 2009-10 billion to 140775.9 billion in 2018-19. The highest increase in GDP Growth Rate of India is 18.66 percent in 2010-11. The compound annual growth rate of GDP was $8.71 \%$ per cent during the study period. The trend values for GDP Growth Rate of India increased from 64238.65 billion in $2009-10$ to 139685.6 billion in $2018-19$ showing an increasing trend for 10 years.

\section{GROWTH OF EXPORT IN INDIA}

Export is a means to create the foreign exchange required to finance the import of goods and services to attain economies of specialization, scale, and scope in production. India has been competent to diversify its exports base from agricultural-based products to manufacturing products

TABLE 3:GROWTH OF EXPORT IN INDIA (Rs.in Billion)

\begin{tabular}{|l|r|r|r|r|}
\hline Year & \multicolumn{1}{|c|}{ Exports } & $\begin{array}{l}\text { Increase/ } \\
\text { Decrease }\end{array}$ & \% & Trend \\
\hline $2009-10$ & 8455.34 & - & - & 10981.42 \\
\hline $2010-11$ & 11429.22 & 2973.88 & 35.17 & 12257.99 \\
\hline $2011-12$ & 14659.59 & 3230.37 & 28.26 & 13534.55 \\
\hline $2012-13$ & 16343.19 & 1683.6 & 11.48 & 14811.12 \\
\hline $2013-14$ & 19050.1 & 2706.91 & 16.56 & 16087.69 \\
\hline $2014-15$ & 18964.5 & -85.6 & -0.45 & 17364.26 \\
\hline $2015-16$ & 17163.8 & -1800.7 & -9.50 & 18640.83 \\
\hline $2016-17$ & 18494.3 & 1330.5 & 7.75 & 19917.39 \\
\hline $2017-18$ & 19555.4 & 1061.1 & 5.74 & 21193.96 \\
\hline $2018-19$ & 23144.3 & 3588.9 & 18.35 & 22470.53 \\
\hline CAGR & $10.59 \%$ & & & \\
\hline
\end{tabular}

Source: Computed

It is observed from Table 3 that the Growth of Export in India was fluctuating between from 19050.1 billion in 2013-14 to19555.4 billion in 2017-18. The highest increase in export of India is 35.17 percent in 2010-11 compared to 2018-19. The compound annual growth rate of 
export from India was 10.59 percent during the study period. The trend values for Growth of Export in India increased from 10981.42 billion in 2009-10 to22470.53 billion in 2018-19 showing an increasing trend for 10 years.

\section{HYPOTHESES OF THE STUDY}

To meet the objectives of the study, the following hypotheses have been formulated:

Ho: There is no significant relationship between

FDI Inflows and Export Performance.

H1: There is a significant relationship between

FDI Inflows and Export Performance.

Ho: There is no significant relationship between

FDI Inflows, GDP growth, and Export

Performance.

H1: There is a significant relationship between FDI Inflows, GDP growth, and Export, Performance

\section{$X$. TESTING OF HYPOTHESES AND DATA ANALYSIS}

To examine the significance of FDI on export and growth, firstly Pearson's correlation coefficient is computed between FDI Inflows and Export Performance, FDI Inflows and GDP growth, GDP growth and Export Performance. The results are analyzed by considering the values of FDI Inflows, GDP growth and Export Performance of India from the period 2009-10 to 2018-19.

TABLE 4 : Correlations of FDI and EXPORT

\begin{tabular}{|c|l|c|c|}
\hline \multicolumn{4}{|c|}{ Correlations } \\
\hline \multirow{2}{*}{ FDI } & $\begin{array}{l}\text { Pearson } \\
\text { Correlation }\end{array}$ & 1 & $.726^{*}$ \\
\cline { 2 - 4 } & Sig. (2-tailed) & & .017 \\
\hline \multirow{2}{*}{ EXPORT } & $\begin{array}{l}\text { Pearson } \\
\text { Correlation }\end{array}$ & $.726^{*}$ & 1 \\
\cline { 2 - 4 } & Sig. (2-tailed) & .017 & \\
\hline & * Correlation is significant at the 0.05 level (2-tailed). \\
\hline
\end{tabular}

Where, $\mathrm{EXP}_{\mathrm{t}}=$ Export Performance

$\mathrm{FDI}_{\mathrm{t}}=$ Foreign Direct Investment

$\mathrm{e}=$ Error or Disturbance term

Source: Computed

Source: Computed Multiple-Regression Analysis. Exports on FDI

$$
\mathrm{EXP}_{\mathrm{t}}=\alpha+\beta \mathrm{FDI}_{\mathrm{t}}+\mathrm{e}
$$

\begin{tabular}{|c|l|c|c|}
\hline \multirow{3}{*}{ GDP } & Sig. (2-tailed) & & .001 \\
& $\begin{array}{l}\text { Pearson } \\
\text { Correlation }\end{array}$ & $.893^{* *}$ & 1 \\
\cline { 2 - 4 } & Sig. (2-tailed) & .001 & \\
\hline \multirow{2}{*}{$* *$ Correlation is significant at the 0.01 level (2-tailed). } \\
\hline
\end{tabular}

TABLE 6:Correlations of GDP and EXPORT

\begin{tabular}{|c|c|c|c|}
\hline \multicolumn{4}{|c|}{ Correlations } \\
\hline & & GDP & EXPORT \\
\hline \multirow[t]{2}{*}{ GDP } & $\begin{array}{l}\text { Pearson } \\
\text { Correlation }\end{array}$ & 1 & $.924 * *$ \\
\hline & Sig. (2-tailed) & & .000 \\
\hline \multirow[t]{2}{*}{ EXPORT } & $\begin{array}{l}\text { Pearson } \\
\text { Correlation }\end{array}$ & $.924 * *$ & 1 \\
\hline & Sig. (2-tailed) & .000 & \\
\hline
\end{tabular}

Since the correlation coefficient between the three variables are quite high, therefore, the null hypothesis in both cases is rejected in a confidence interval of 0.01 and 0.05 alternative hypotheses are accepted. The results prove that there is a significant relationship between FDI Inflows, GDP growth, and Export Performance.

To further understand the dependency of these three variables, the following models have been built based on Simple Regression and

MODEL 1: The first model is based on Simple Regression analysis to explain the dependency of

TABLE 7: Simple Regression

\begin{tabular}{|c|c|c|c|c|c|c|c|}
\hline \multirow{4}{*}{\multicolumn{4}{|c|}{ TABLE 5: Correlations of FDI and GDP }} & \\
\hline & & & & \multicolumn{4}{|c|}{ Coefficients } \\
\hline & & & & \multirow{3}{*}{$\frac{\text { Model 1 }}{\text { (Constant) }}$} & \multicolumn{2}{|c|}{ Coefficients } & \multirow[b]{2}{*}{$\mathbf{t}$} \\
\hline & & & & & $\boldsymbol{\beta}$ & Std. Error & \\
\hline \multicolumn{4}{|c|}{ Correlations } & & 6870.371 & 3443.214 & 1.995 \\
\hline & & FDI & GDP & FDI & 4.614 & 1.545 & 2.987 \\
\hline FDI & $\begin{array}{l}\text { Pearson } \\
\text { Correlation }\end{array}$ & 1 & $.893 * *$ & \multicolumn{4}{|c|}{ Dependent Variable: EXPORT } \\
\hline
\end{tabular}

TABLE 8: ANOVA (Model Summary)

\section{ANOVA (Model Summary)}

\begin{tabular}{|l|l|l|l|c|c|c|}
\hline Model & R & R Square & Adjusted R Square & $\begin{array}{c}\text { Std. Error of the } \\
\text { Estimate }\end{array}$ & F- test** & Durbin-Watson \\
\hline
\end{tabular}




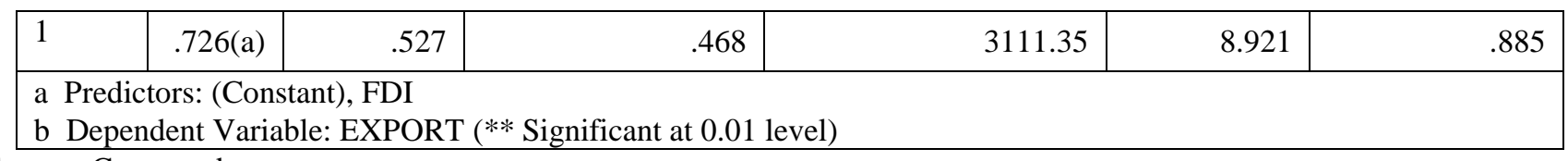

Source: Computed

From Model 1, it is revealed that all the variables are statistically significant. The regression result confirms that FDI is an essential factor for an increase in exports in the country. It is observed from the results that the elasticity coefficient between FDI Inflows and Export Performane is 4.61 which mean that a $1 \%$ increase in FDI may cause $4.61 \%$ increase in exports. Thus FDI Inflows positively influences exports. The coefficient of determination i.e., $\mathrm{R}^{2}$ shows that the model has a good fit as $52 \%$ of exports are being explained by FDI. F-test also confirms that the variables are statistically significant. The Durbin-watson statistic shows that there is no autocorrelation problem in the analysis.

MODEL 2: Model 2 is based on Multiple Regression Analysis to prove the dependence of GDP on Export and FDI.
Where, $\mathrm{GDP}_{\mathrm{t}}=$ Gross Domestic Product

$\mathrm{EXP}_{\mathrm{t}}=$ Export Performance

$\mathrm{FDI}_{\mathrm{t}}=$ Foreign Direct Investment

$\mathrm{e}=$ Error or Disturbance term

TABLE 9:Multiple Regression

\begin{tabular}{|c|c|c|c|}
\hline \multicolumn{4}{|c|}{ Coefficients } \\
\hline \multirow[t]{2}{*}{ Model 2} & \multicolumn{2}{|c|}{ Coefficients } & \multirow[t]{2}{*}{$\mathbf{t}$} \\
\hline & $\beta$ & Std. Error & \\
\hline (Constant) & 5783.141 & 8035.592 & .720 \\
\hline FDI & 17.781 & 4.284 & 4.151 \\
\hline EXPORT & 3.479 & .674 & 5.161 \\
\hline ependent $\mathrm{Va}$ & & & \\
\hline
\end{tabular}

Source: Computed

$\mathrm{GDP}_{\mathrm{t}}=\alpha+\beta 1 \mathrm{FDI}_{\mathrm{t}}+\beta 2 \mathrm{EXP}_{\mathrm{t}}+\mathrm{e}$

TABLE 10:ANOVA (Model Summary)

\begin{tabular}{|l|c|c|c|c|c|c|}
\hline \multicolumn{7}{|c|}{ ANOVA (Model Summary) } \\
\hline Model & R & R Square & $\begin{array}{c}\text { Adjusted R } \\
\text { Square }\end{array}$ & $\begin{array}{c}\text { Std. Error of the } \\
\text { Estimate }\end{array}$ & F- test** Durbin-Watson \\
\hline 2 & $.979(\mathrm{a})$ & .958 & .946 & 5933.27 & 79.281 & 1.788 \\
\hline $\begin{array}{l}\text { a Predictors: (Constant), EXPORT, FDI } \\
\text { b Dependent Variable: GDP (** Significant at 0.01 level) }\end{array}$ \\
\hline
\end{tabular}

In the growth model (Model 2), estimated coefficients on FDI and Export Performance have a positive relationship with GDP. Therefore, it is statistically revealed that FDI and Export are contributory in influencing the level of fiscal growth in India. The coefficient of determination i.e., R2 explains that $96 \%$ level of economic growth is being influenced by FDI and export in India. The F-test also confirms the significant relationship between FDI Inflows, GDP growth, and Export Performance. The Durbin-watson statistic is 1.788 which is confirm that there is no autocorrelation problem in the analysis.

\section{FINDINGS OF THE STUDY}

1. The results of the export model (model 1) show that both the variable included under study are statistically significant. The elasticity of the coefficient between exports and FDI Inflows is positive which indicates that a $1 \%$ increase in FDI Inflows can increase $4.61 \%$ of exports.

2. In the GDP model (model 2), the variables under study proved to be statistically significant indicating that FDI Inflows and exports play a vital role in accelerating the GDP of Indian Economy.

3. The study also shows that FDI and exports, FDI and GDP, GDP and Exports are all positively and highly correlated with each other which pave the way for rejecting the null hypotheses and accepting the alternative hypotheses under consideration.

\section{CONCLUSION}

The study reveals that Foreign Direct Investment not, only acts as a vehicle for accelerating the pace exports but it is also an important variable that alters the level of GDP of the Indian economy. It can complement local developmental efforts by boosting export competitiveness, generating employment and strengthening the skill base, improving technological abilities (transfer, diffusion, and generation of technology), and increasing financial resources for development. Exports have emerged as a strategic instrument for economic and social development and need not be treated as a residual activity. There is an imperative need to fine-tune FDI policies and incentives for raising export-orientation of foreign investment. India should continue to take steps to ensure an enabling business environment to improve India's attractiveness as an investment destination. The government has taken several measures like fixing timeliness for approvals and streamlining procedures to improve ease of doing business in the country, and attract foreign investments 


\section{REFERENCES}

[1] Sharma K (2000) Export Growth in India- has FDI Played a Role? Yale University Discussion Paper No.816.

[2] Ramkishen S. Rajen, S. M. (2009). 'How can India Increase its Attractiveness as a Destination for FDI?' In R. S. Rajen Monetary Investment and Trade Issues in India (pp. 127-151). New-Delhi: Oxford.

[3] Joseph TJ and Reddy N (2009) FDI Spillovers and Export Performance of Indian Manufacturing Firms after Liberalisation Economic and Political Weekly. 44( 52):97-105

[4] Atif, M. A.-u.-R. (2012). "Impacts of Imports, Exports, and Foreign Direct Investment on the Gross Domestic Product Growth". International Conference of Business Management. Lahore.

[5] Sultan, Z. A. (2013). A causal relationship between FDI inflows and export: The case of India. Journal of Economics and Sustainable Development, 4(2), 1-9

[6] Sahoo, K., \&Sethi, N. (2017). Impact of foreign capital on economic development in India: An econometric investigation. Global Business Review, 18(3), 766-780 